\title{
Effect of odontoplasty on apparent digestibility and consumption time of diet for equines
}

\author{
[Efeito da odontoplastia sobre a digestibilidade aparente e o tempo de consumo de \\ dieta para equinos] \\ F.C.D. Araújo, M.G. Cruz, J.C.C. Balieiro, M.L. Menezes, C.G. Moreira, C. Giunco, \\ G.F. Correa, R.A. Brandi* \\ Universidade de São Paulo - USP - Pirassununga, SP
}

\begin{abstract}
The aim of this study was to investigate the effect of odontoplasty on apparent digestibility of diet for horses, consumption time, and particle size of feces. Nine horses were used, aged 14.5 \pm 3.3 years and weightng $531 \pm 38.7 \mathrm{~kg}$. The diet consisted of $1.5 \%$ of live weight (LW) in Tifton 85 hay and $0.75 \%$ of LW in concentrate for both assays. The experiment consisted of two tests of apparent digestibility using the method of total collection, before and after the odontoplasty, where the consumption time of hay and concentrate was also evaluated and the particle size of the feces was analyzed. An effect $(\mathrm{P}<0.05)$ of odontoplasty on the apparent digestibility coefficients of dry matter, organic matter, crude protein, neutral detergent fiber and acid detergent fiber was observed. Effect of the consumption time for the concentrate $(\mathrm{P}<0.05)$ was observed, but not for the forage $(\mathrm{P}<0.05)$. There was more retention $(\mathrm{P}<0.05)$ of the fecal particles in the sieves of bigger granulometry. The odontoplasty increases the digestibility of dietary nutrients and feces particle size, without changing feces quality. Animals after the procedure have shorter concentrate consumption time.
\end{abstract}

Keywords: horses, nutrition, performance, dentistry

\section{RESUMO}

O objetivo deste estudo foi investigar o efeito da odontoplastia sobre a digestibilidade aparente de dieta para equinos, o tempo de consumo e o tamanho de partícula das fezes. Foram utilizados nove equinos,

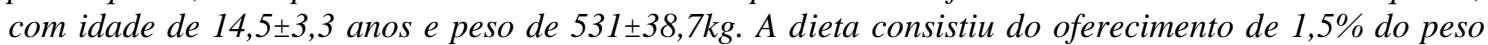
vivo $(P V)$ em feno de Tifton 85 e $0,75 \%$ do PV em concentrado para ambos os ensaios. $O$ experimento compôs-se de dois ensaios de digestibilidade aparente pelo método de coleta total, antes e após a odontoplastia, em que também foi avaliado o tempo de consumo do feno e do concentrado e analisado o tamanho de partícula das fezes. Foi observado efeito $(P<0,05)$ da odontoplastia sobre os coeficientes de digestibilidade aparente da matéria seca, matéria orgânica, proteína bruta, fibra em detergente neutro e fibra em detergente ácido. Verificou-se efeito do tempo de consumo para o concentrado $(P<0,05)$, porém não se observou para o volumoso $(P<0,05)$. Houve maior retenção $(P<0,05)$ das partículas das fezes nas peneiras de maior granulometria. A odontoplastia aumenta a digestibilidade dos nutrientes da dieta e o tamanho de partículas nas fezes, sem alterar a qualidade destas. Animais após o procedimento apresentam menor tempo de consumo de concentrado.

Palavras-chave: cavalos, nutrição, desempenho, odontologia

Recebido em 23 de fevereiro de 2017

Aceito em 28 de abril de 2017

* Autor para correspondência (corresponding author)

E-mail: robertabrandi@usp.br 


\section{INTRODUCTION}

Dentistry has been shown to be an important tool to allow a good quality of life, health maintenance and improvement in the sport performance for equines (Alencar-Araripe et al., 2013). Horses with dental sharp enamel points grind foods poorly, have delayed digestion, present progressive weight loss and predisposition to high incidence of colic (Thomassian, 2005). It is common in the equine dentistry routine that corrections increase the ability of the animal to chew food and thereby increase digestibility (Ralston et al., 2001).

Studies about the effect of odontoplasty on the digestibility of diets are scarce and divergent. Ralston et al. (2001), Carmalt; Carmalt. (2004), Moraes Filho (2016) have observed no effect of the procedure, while Pagliosa et al. (2006), Zwirglmaier et al. (2013), Zwirglmaier et al. (2013) ob observed effect. The comparison of the studies is difficult because of the divergence of the experimental protocols applied, the degree and types of dental alterations observed in each protocol and the methodology used to determine the digestibility (Zwirglmaier et al., 2013).

In addition to the evaluation of digestibility, some accessory parameters can be used to determine the efficacy of odontoplasty, such as the determination of consumption time and food intake (Dixon and Dacre, 2005; Bonin et al., 2007), a decrease in consumption time after the procedure was observed before. Another parameter is the size particles in faeces Carmalt; Carmalt., 2004, and Zwirglmaier et al., 2013), it was not observed decrease in particle size after the procedure in these studies.

The present study aimed to investigate the effect of odontoplasty on apparent digestibility of diet for horses, consumption time and particle size of feces.

\section{MATERIAL AND METHODS}

The project was approved by the Research Ethics Committee of the Faculty of Animal Science and Food Engineering, under protocol number 14.1.476.74.4.

The tests were conducted at the Equine Sector of the University of São Paulo (USP), Campus
Fernando Costa, at the Faculty of Animal Science and Food Engineering (FZEA- USP).

Nine horses were used, five males and four females, with live weight of $531 \pm 38.7 \mathrm{~kg}$ and aged $14.5 \pm 3.3$ years, in which excessive dental sharp enamel points (DSEP) were found in the same patterns.

The experiment was divided in two trials, one before and the other after the odontoplasty. In both periods, the consumption time of forage and concentrate, the apparent digestibility of nutrients, and color, consistency, and particle size of feces were evaluated.

The diet consisted of $1.5 \%$ of live weight (LW) in forage (Tifton hay) and $0.75 \%$ of $\mathrm{LW}$ in multiparticle concentrate (Pro-Equi ${ }^{\circledR}$ Lamina) for both trials (Table 1). The diet was formulated to meet the requirement of animals in maintenance as described by NRC (Nutrient..., 2007).

Table 1. Bromatological Composition of Tifton Hay and Commercial Concentrate used in the diet

\begin{tabular}{|c|c|c|}
\hline Nutrient/ingredient & Tifton hay & Concentrate \\
\hline Dry matter & 96.65 & 98.65 \\
\hline Organic matter & 93.74 & 88.44 \\
\hline $\begin{array}{l}\text { Acid Detergent } \\
\text { Fiber }\end{array}$ & 34.24 & 12.43 \\
\hline $\begin{array}{l}\text { Neutral detergent } \\
\text { fiber }\end{array}$ & 73.4 & 32.06 \\
\hline Hemicellulose & 39.15 & 19.63 \\
\hline Crude protein & 11.5 & 13.4 \\
\hline Estimated energy & 2.42 & 3.38 \\
\hline \multicolumn{3}{|c|}{$\begin{array}{l}\text { Hay energy estimated by the equation: DEest } \\
(\mathrm{Mcal} / \mathrm{Kg})=4.22-0.11 *(\% \mathrm{ADF})+0.0332 *(\% \mathrm{CP})+ \\
0.00112 *\left(\% \mathrm{ADF}^{2}\right), \text { for forage and DEest }(\mathrm{Kcal} / \mathrm{kg})= \\
4.07-0.055 *(\% \mathrm{ADF}) \text { for concentrate described by } \\
\text { NRC (Nutrient..., 2007). }\end{array}$} \\
\hline
\end{tabular}

The animals were fed with forage at 7:00a.m. and 2:00p.m. and with concentrate at 10:00a.m. and 5:00p.m. For the determination of the forage and concentrate consumption time, one kilo of each food was offered to the animal and the time was determined. Immediately, the remaining amount of food referring to that meal was offered, completing the diet.

For determination of apparent digestibility of nutrients, the animals were submitted to 10 days 
of adaptation to the diet, followed by four days of total collection of feces.

The bromatological analyzes of food and feces were carried out at the Laboratory of Bromatology of the Department of Animal Science of FZEA -USP and the calcium and phosphorus analysis were performed at the Minerals Laboratory of the Department of Animal Science of FZEA-USP. The Dry Matter (DM), Mineral Matter (MM), Crude Protein (PB), Ether Extract (EE), Gross Energy (GE), Neutral Detergent Fiber (NDF), Acid Detergent Fiber (ADF), Organic Matter (MO) and Hemicellulose (HEM) were determined.

The analysis of DM, MM, CP and EE were performed according to the methodology described by the Association of Official Analytical Chemistry (Official..., 1995). The NDF and ADF determinations were performed according to Van Soest (1994) and the GE was analyzed through the use of C-200 calorimetric pump. The apparent digestibility coefficients of DM, OM, CP, NDF, ADF, GE and HEM were determined according to equations suggested by Andriguetto et al., (1994).

Immediately after the first trial, odontoplasty was performed. For this, the animals were fasted for 12 hours and their oral cavity was washed with running water to remove any dirt. Then, sedation with detomidine at the dose of $0.02 \mathrm{mg} / \mathrm{kg}$ intravenous was performed. A specific mouthpiece for horses, Mcpherson type, was used for inspection of the oral cavity, with light focus and dental mirror for detailed visual inspection of the other dental elements (premolars and molars). For the removal of DSEP, two proper dental pens were used, connected to a high rotation motor. The entire procedure did not exceed 60 minutes, and the animal stayed in the horse stock under observation until complete recovery of sedation.

After the procedure, the animals were turned out in the pasture for 3 days and then underwent to a new phase of the experiment.

The consistency and color characteristics of the feces were evaluated during the collection for digestibility trial, using the first feces of the day. For fecal consistency, scores ranging from 1 to 5 were attributed, with 1 - highly dry, 3 - normal and 5 - diarrheic (Berg et al., 2005). For the characteristic color the feces, it was classified as greenish (normal), black, reddish or yellowish (Gonçalves et al., 2006).

To determine the feces particle size, samples of $250 \mathrm{~g}$ of dried feces were placed on an automatic shaker and sieves with 4.75, 4, 2.8, 1.4, 1 mesh were used and the bottom of the sieves, coupled. The sample shaking time was 10 minutes. After the stirring process, the sample amounts retained in each sieve were weighed and the values converted into percentages for the appropriate comparisons between the sieves.

For the variables consumption time (minutes) and apparent digestibility of the nutrients, the data were submitted to ANOVA, analyzed using the Statistical Analysis System (SAS, 2004) software, through the MIXED procedure. The variables color and consistency of feces were analyzed by the chi-square test.

\section{RESULTS AND DISCUSSION}

In the visual inspection of the selected horses, it was observed that $100 \%$ of them had DSEP, $66.7 \%$ had rostral hooks, $100 \%$ caudal hooks, $22.2 \%$ fractures, $33.3 \%$ steps, $66.7 \%$ waves, $33.3 \%$ ramps and $44.44 \%$ other conditions such as extraction need, periodontal disease and impacted tooth.

All the changes described and observed in the group of animals studied present a marked influence on the use of food and animal welfare (Dixon and Dacre, 2005), each with its particularity (Faria, 2012).

The highest prevalence of dental sharp enamel points in the animals used in this research can also be attributed to the age of the animals, $14.5 \pm 3.3$ years, and the absence of previous treatment for dental alterations. As the animals remained in an extensive breeding system, it was not possible to verify restriction of food consumption, however, it was observed that they presented body conditions consistent with animals in this system.

Effect of odontoplasty $(\mathrm{P}<0.05)$ was not observed on the consumption time of forage, but effect on the consumption time of the concentrate $(\mathrm{P}<0.05)$ was observed (Table 2$)$, 
data that corroborates with Simhofer et al. (2011), who have studied the effect of correction of dental alterations on the kinetics of the chewing in horses, and observed that the mean duration of the masticatory cycle was 0.70 seconds for the animals fed with forage.

Lorenzo-Figueras et al. (2002), studying the tonus of the stomach after the supply of forage and concentrate, observed that the consumption time of $0.5 \mathrm{~g} / \mathrm{kg}$ of PV of the hay was 617 seconds, and 176 seconds for the concentrate. Applying this relation on the weight of the equines used in the present research, the consumption time for $1 \mathrm{~kg}$ of hay should be 38.7 minutes, 11.04 minutes for grains or concentrate, values lower than those observed. It can be attributed to the methodology of determination of this parameter, since the animals of the cited research had a balloon in the stomach, simulating satiety.

It is interesting to note that the relationship suggested by Lorenzo-Figueras et al. (2002) for the consumption time of forage and grains is similar to that observed in the present study of $3.5: 1$, what means, the time spent by the animal to ingest forage is three times longer compared to the time used for eating concentrate.

Table 2. Mean consumption time (hours) of forage and concentrate (minutes), standard error and coefficient of variation $(\mathrm{CV})$, before and after odontoplasty

\begin{tabular}{ccccc}
\hline Ingredient/Consumption time & $\begin{array}{c}\text { Before } \\
\text { odontoplasty }\end{array}$ & $\begin{array}{c}\text { After } \\
\text { odontoplasty }\end{array}$ & CV (\%) & P value \\
\hline Tifton hay & $1.32 \pm 0.13$ & $1.1 \pm 0.13$ & 43.75 & 0.2019 \\
Concentrate & $23.65 \pm 1.53$ & $17.33 \pm 1.49$ & 32.84 & 0.0108 \\
\hline
\end{tabular}

The results observed in the present study are superior to those reported by Meyer (1995) for the consumption time of forage (40-60 minutes $/ \mathrm{kg}$ of product) but are similar for the concentrate consumption time (20 minutes $/ \mathrm{kg}$ of product). According to this author, some factors can influence the consumption for example: the structure and consistency of the food, individual variation and specie or breed. In the present study, the neutral detergent fiber content $(73.2 \%)$ may have contributed to the observation of a longer period of consumption.

Considering the coefficient of variation of the data (Table 2), it can be suggested an individual effect, since high values observed refer to the difference observed in the consumption time of the animals, data that disagree with Zwirglmaier et al. (2013), who did not observe difference in the amount of dry matter ingested per $\mathrm{kg}$ of live weight of the animal per day and, thus the consumption time was also not influenced.

The consumption time of the concentrate dropped from $23.62 \pm 1.53$ minutes to $17.33 \pm 1.49$ $(\mathrm{P}<0.05)$, after odontoplasty, data that corroborate with Dixon and Dacre (2005) who mentioned that dental problems lead to increased ingestion time. It can be attributed to ease of occlusion and masticatory movements after odontoplasty (Simhofer et al., 2011) and the transitory increased number of vertical movements attributed to dental surface smoothing, as described by Bonin et al. (2007).

The aforementioned transitory verticalization of the masticatory movement may also have influenced the decrease $(\mathrm{P}>0.05)$ in the consumption time of the forage, presenting values before and after odontoplasty, respectively 79.2 and 66 minutes. It is also believed that the decrease in the chewing time is a transitory situation since the second digestibility test was performed in a short time after the procedure and the animals did not have time to adapt themselves to the new situation. In addition, when dental changes were solved, mandibular movements were facilitated and then, less jaw strength was required for the execution of masticatory movements (Dixon and Dacre, 2005), which may have led to the need for shorter chewing. In addition, the animal was probably adapting the entire facial musculature to provide amplitude in the cycle of masticatory movement (Baker, 2002).

According to Bonin et al. (2007), the masticatory movements change according to physical properties of the food, and the jaw performs more lateral excursion when the horses chew food with high moisture content, high fiber content or larger particle size. As the two foods 
used in the present study were dry foods with similar humidity, it is believed that the difference between concentrate and forage time consumption is related to fiber ratio and particle size; and the difference can be explained because fibrous foods, such as hay or other forages, are more easily held on the occlusal surface of the mandibular teeth of the cheek when the mandible moves laterally thus allowing complete horizontal milling. When chewing particulate foods, such as grain and feed pellets, the relatively small amount of feed can be positioned on the mandibular occlusal surface and its retention is facilitated when mandibular movements are mostly vertical with minimal lateral excursion (Bonin et al., 2007).

The lower consumption time of the diet could have negatively influenced the utilization of this, a situation that did not occur in the present study. The higher apparent digestibility coefficients of the diet were observed after the odontoplasty for dry matter (DM), organic matter (OM), crude protein $(\mathrm{PB})$, neutral detergent fiber (NDF), acid detergent fiber (ADF) and hemicellulose (HEM) (Tab. 3).

Table 3. Mean apparent digestibility coefficients of dietary nutrients, before and after odontoplasty

\begin{tabular}{ccccc}
\hline $\begin{array}{c}\text { Apparent digestibility coefficients of } \\
\text { dietary nutrients }(\%)\end{array}$ & $\begin{array}{c}\text { Before } \\
\text { odontoplasty }\end{array}$ & $\begin{array}{c}\text { After } \\
\text { odontoplasty }\end{array}$ & CV (\%) & P Value \\
\hline Dry matter & 56.6 & 62.2 & 8.5 & 0.0282 \\
Organic matter & 58.4 & 64.3 & 10.1 & 0.0532 \\
Crude Protein & 65.3 & 75.4 & 8.9 & 0.0006 \\
Neutral detergent fiber & 46.6 & 53.4 & 9.6 & 0.0022 \\
Acid detergent fiber & 38.1 & 43.7 & 11.4 & 0.0201 \\
Hemicellulose & 52.6 & 60.9 & 8.0 & $<.0001$ \\
\hline
\end{tabular}

The digestibility coefficients obtained in the present research were higher than those cited by Araujo et al. (2000), working with diets based exclusively on Coast Cross hay and close to those obtained by Furtado et al. (1999), also working with Coast Cross hay diets.

Giunco et al. (2016), working with diets with a ratio of $70 \%$ of forage and $30 \%$ of concentrate, obtained apparent digestibility values of DM, $\mathrm{OM}$ and $\mathrm{CP}$ similar to those obtained in this research before odontoplasty. However, for the fiber fraction the values were lower, which can be attributed to the quality of the forage used in this research, the same situation observed by Correa et al. (2016).

Studies on the digestibility of the diets before and after the DSEP correction are scarce (Carmalt; Carmalt, 2004; Moraes Filho, 2016; Ralston et al., 2001; Pagliosa et al., 2006; Zwirglmaier et al., 2013).

Unlike the results in the present study, Carmalt et al. (2004), working with three different diets for pregant mares, did not observe differences on nutrient digestibility (DM, NDF, ADF, CP) before and after odontoplasty, which was attribute to the diet composition (straw with different grains) and the presence of four different diets composing the digestibility information after the odontoplasty.

Also in disagreement with the data obtained in the present study, Moraes Filho (2016), studying the effect of odontoplasty in horses over time (before, 20, 40 days after odontoplasty), did not observe effect $(\mathrm{P}>0.05)$ of this procedure on the digestibility of DM, CP, NDF, EE, OM, but an effect $(\mathrm{P}<0.05)$ was observed for the ADF after 20 days. When comparing the data obtained in the present research and the aforementioned author, it was observed that the digestibility coefficients obtained prior to the correction of DSEP were higher than those observed in the present study, which may have contributed to the non-observation of difference before and after the correction of DSEP. The author did not report the dental changes detected and thus the comparison of the studies is impaired.

The biggest gap observed in the comparison between the studies performed in the odontoplasty area is the difference of the experimental protocols and the lack of information regarding the severity of dental anomalies observed before the procedure. Studies have used different diets to evaluate digestibility before and after odontoplasty (Carmalt; Carmalt, 2004), which may lead to 
more aggregation of error in the final result, while the present research and Zwirglmaier et al. (2013), both worked with a single diet and obtained significant results of odontoplasty on the digestibility of dietary nutrients.

The number of animals analyzed per experiment can be a differential and their individualized monitoring can be a determinant in obtaining the results. The studies consulted, used about 8 to 10 animals, which for equine research is quite considerable, since all of them were in similar conditions regarding dental problems. The individualized analysis of the experimental horses may contribute to a better accuracy of information, since the individual effect has previously been reported by Kienzle et al. (1994).

Ralston et al. (2001), evaluating two methodologies for DSEP correction, performed digestibility tests before, 2 and 4 weeks after the procedure, evaluated the animals through differentiation of dental angulations and reported that the anomalies found were light. No effect of procedures on nutrient digestibility (DM, CP, FDA and NDF) was observed before and two weeks after the DSEP correction, but an effect was observed for FDA and NDF four weeks later. The digestibility coefficients before the procedure were similar to those obtained in the present study, but the digestibility coefficients after odontoplasty were lower, which may be related to the degree of the anomalies (being more severe in this study than in the aforementioned study) and the methodology of determination of digestibility over time.

It is interesting to note the alteration $(\mathrm{P}<0.05)$ of digestibility observed in the fibrous fraction of the present study after odontoplasty, since the dental correction may be closely related to the chewing cycle as reported by Bonin et al. (2007), which directly influences the digestibility of this fraction. It reiterates the importance of odontoplasty for equines.

Zwirglmaier et al. (2013), working with diets based on hay and grains, observed the effect of odontoplasty on the digestibility of DM, GE, non-nitrogenous extract and crude fiber. The digestibility experiments were carried out 3 days before and 3 days after DSEP correction, the methodology that was closer to the one used in the present research and that may have influenced the significant digestibility differences before and after the procedure in both investigations.

Pagliosa et al. (2006), offering diets based on chopped grass and concentrate, also observed the effect of odontoplasty on nutrient digestibility. It is not possible to compare the digestibility coefficients obtained since the diets and protocols were very different.

When considering the increase of digestibility of dietary nutrients, as observed in this research, it was expected a decrease in the particle size, with consequently more action of the digestive secretions and with that, higher digestibility, as described by Meyer (1995), a more significant reality for concentrate than for forage. However, according to Zwirglmaier et al. (2013), particle size data in feces are contradictory and unexpected.

It was observed effect of odontoplasty $(\mathrm{P}<0.05)$ on the feces particle size in the sieves of $4.75,4$ and 2.8 with more retention after the procedure, but no effect $(\mathrm{P}<0.05)$ was observed for the sieves of 1.4, 1.0 and the background, reporting that odontoplasty did not decrease particle size; results corroborating with those observed by Carmalt; Carmalt, (2004) and Zwirglmaier et al (2013). The quality of the feces obtained in this study was not affected by odontoplasty, remaining as $100 \%$ greenish, which are considered normal (Gonçalves et al., 2006), as well as showing normal consistency (Berg et al., 2005) and score 3.

One of the factors that may have influenced the achievement of these results is the severity level of the DSEP in the different studies, and may suggest that, in the present study, the lighter degree of alterations may have led to higher digestibility coefficients, even without decreasing the size of the particles.

Another factor that may have contributed to this result is the predominance of forage in the diet. All the nutrient digestibility coefficients obtained in this study are close to the observed for diets based exclusively on forage or with predominance of this source, which leads to suggest that the concentrate had little action and then, the feces particle size refer to the forage. 
Different from what is intended for the concentrate, for the forage, it was not expected the decreasing of the particle size, but rather the degree of maceration (Meyer, 1995), which may have favored the intestinal flora action in the diet, resulting in higher digestibility coefficients after odontoplasty.

The presence of larger particles may have led to a longer retention of the diet in the large intestine and, therefore, favored fiber digestibility, as previously described by Frape (2008).

The difference in the methodology used for feces particle size analysis is a factor that strongly influences the data and does not allow a safe comparison between the literature studies (Carmalt; Carmalt, 2004).

\section{CONCLUSION}

Odontoplasty increases the digestibility of dietary nutrients and feces particle size without changing color and consistency characteristics. Animals after the procedure have shorter concentrate consumption time.

\section{REFERENCES}

ALENCAR-ARARIPE, M.G.; COLLARES, D.S.; CASTELO BRANCO, M. et al. Alterações anatomopatológicas na cavidade oral equina. Acta Vet. Brasilica, v.7, p.184-192, 2013.

ANDRIGUETTO, J.M.; PERLY, L.; MINARDI, I.; GEMAEL, A.; FLEMMING, J.S.; SOUZA, G.A.; BONA FILHO, A. Nutrição animal. São Paulo: Nobel, 1994. 396p.

ARAÚJO, K.V.; LIMA, J.A.F.; FIALHO, E.T. et al. Comparação entre indicadores internos e o método da coleta total na determinação da digestibilidade dos nutrientes de alimentos volumosos, em equinos. Rev. Bras. Zootec., v.29, p.745-751, 2000.

BAKER, G.J. Equine temporomandibular joints (TMJ): morphology, function and clinical disease. In: AMERICAN ASSOCIATION EQUINE PRACTITIONES, 48., 2002, Orlando. Proceedings... Orlando: AAEP, 2002. p.442447.
BERG, E.L.; FU, S.J.; PORTER. et al. Fructooligosaccharide supplementation in the yearling horse: effects on fecal $\mathrm{pH}$, microbial content, and volatile fatty acid concentrations. $J$. Anim. Sci., v.83, p.1549-1553, 2005.

BONIN, S.J.; CLAYTON, H.M.; LANOLAZ, J.L. et al. Comparison of mandibular motion in horses chewing hay and pellets. Equine Vet. J., v.39, p.258-262, 2007.

CARMALT, J.L.; CARMALT, K.P. Equine dentistry-what do we really know? J. Vet. Dent., v.40, p.134-135, 2004.

CORREA, G.F.; NASCIMENTO, O.C.A.; MOTA, T.P. et al. Impact on digestibility, and blood and fecal parameters of replacing wheat bran with corn gluten meal in concentrate of adult horses. Livest. Sci., v.186, p.41-45, 2016.

DIXON, P.M.; DACRE, I. A review of equine dental disorders. Vet. J., v.169, p.165-187, 2005.

FARIA, C.V.M. Estudo descritivo de alterações dentárias de equídeos utilizando a radiografia e a tomografia como métodos auxiliares de diagnóstico. 2012. 83f. Dissertação (Mestrado em Ciência Animal) - Ciências Agrárias, Veterinária, Universidade Federal de Goiás, Goiânia, GO.

FRAPE, D. Nutrição \& alimentação de equinos. São Paulo: Roca, 2008. 602p.

FURTADO, C.E.; CABRERA, L.; FONSECA, N.A.N. et al. Avaliação da digestibilidade aparente de fenos de gramíneas e de leguminosa para equinos. Acta Sci. Anim. Sci., v.21, p.651655, 1999.

GIUNCO, C.; RIBEIRO, G.; BERTIPAGLIA, L.M.A. et al. Defatted maize germ in equine diets. Biosci. J., v.32, p.1305-1313, 2016.

GONÇALVES, S.; LEBLOND, A.; DROGOUL, C. et al. Using feces characteristics as a criterion for the diagnosis of colic in the horse: a clinical review of 207 cases. Rev. Med. Vet., v.157, p.3$10,2006$.

KIENZLE, E.; RADICKE, S.; LANDES, E. t al. Activity of amylase in the gastrointestinal tract of the horse. J. Anim. Physiol. Anim. Nutr., v.72, p.234-241, 1994. 
LORENZO-FIGUERAS, M.; JONES, G.; MERRITT, A.M. Effects of various diets on gastric tone in the proximal portion of the stomach of horses. Am. J. Vet. Res., v.63, p.1275-1278, 2002.

MEYER, H. Bases anatômicas e fisiológicas. In: __ Alimentação de equinos. São Paulo: Varela, 1995. 300p.

MORAES FILHO, L.A.J. Efeito do tratamento odontológico sobre parâmetros digestivos $e$ metabólicos de equinos. 2016. 88f. Dissertação (Mestrado em Nutrição e Produção Animal) Faculdade de Medicina Veterinária e Zootecnia, Universidade de São Paulo, Pirassununga, SP.

NUTRIENT requirements of horses. Washington: National Academies Press, 2007. $341 \mathrm{p}$.

OFFICIAL methods of analysis. Arlington: AOAC International, 1995.

PAGLIOSA, G.M.; ALVES, G.E.S.; FALEIROS, R.R. Influência das pontas excessivas de esmalte dentário na digestibilidade e nutrientes de dietas de equinos. Arq. Bras. Med. Vet. Zootec., v.58, p.94-98, 2006.
RALSTON, S.L.; FOSTER, D.L.; DIVERS, T. et al. Effect of dental correction on feed digestibility in horses. Equine Vet. J., v.4, p.390395, 2001.

SAS system for windows. Release 8.01. Cary: SAS Institute, 2000.

SIMHOFER, H.; NIEDERL, M.; ANEN, C. et al. Kinematic analysis of equine masticatory movements: Comparison before and after routine dental treatment. Vet. J., v.190, p.49-54, 2011.

THOMASSIAN, A. Enfermidades dos equinos. São Paulo: Varela, 2005. 573p.

VAN SOEST, P.J. Nutritional ecology of the ruminant. Ithaca: Cornell University Press, 1994. 476p.

ZWIRGLMAIER, S.; REMLER, H.P.; SENCKENBERG, E. et al. Effect of dental correction on voluntary hay intake, apparent digestibility of feed and faecal particle size in horse. J. Anim. Physiol. An. Nutr., v.97, p.72-79, 2013. 